\title{
Impaired gap junctions in human hepatocellular carcinoma limit intrinsic oxaliplatin chemosensitivity: A key role of connexin 26
}

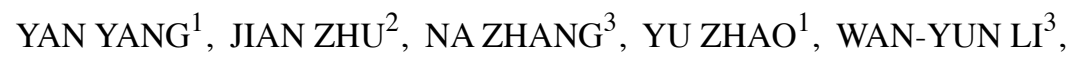 \\ FU-YOU ZHAO ${ }^{1}$, YU-RONG OU ${ }^{3}$, SHU-KUI QIN ${ }^{4}$ and QIONG WU ${ }^{1}$ \\ Departments of ${ }^{1}$ Medical Oncology, ${ }^{2}$ Cardiovasology and ${ }^{3}$ Pathology, The First Affiliated Hospital \\ of Bengbu Medical College, Bengbu, Anhui 233004; ${ }^{4}$ Department of Medical Oncology, \\ PLA Cancer Center, Nanjing Bayi Hospital, Nanjing, Jiangsu 210002, P.R. China
}

Received October 8, 2015; Accepted November 12, 2015

DOI: 10.3892/ijo.2015.3266

\begin{abstract}
Hepatocellular carcinoma (HCC) is generally believed to have low sensitivity to chemotherapeutic agents including oxaliplatin (OXA). Studies have demonstrated that gap junctions (GJs) composed of connexin $(\mathrm{Cx})$ proteins have the potential to modulate drug chemosensitivity in multiple tumor cells. In the present study, we investigated the characteristics of $\mathrm{Cx}$ and GJs in HCC at both histologic and cytologic levels, and the effects of GJ and its effective components on OXA cytotoxicity in HCC cells in vitro. Immunohistochemistry was performed in $76 \mathrm{HCCs}$ and 20 normal liver tissues to detect and locate the expression of $\mathrm{Cx} 26, \mathrm{Cx} 32$ and $\mathrm{Cx} 43$. At cytologic levels, the expression and localization of Cxs were evaluated by RT-PCR, western blot and immunofluorescence assay, respectively. The GJ function between adjacent cells was detected using dye transfer assay. The role of GJs in the modulation of OXA toxicity in HCC cells was explored using pharmacologic and molecular biologic methods. We found that $\mathrm{Cx}$ expression in HCC tissues was significantly lower than in normal liver tissues, and the 'internalization' from cell membrane to cytoplasm was remarkable. In vitro experiments revealed the presence of functional GJs in the SMMC-7721 HCC cells due to a small amount of $\mathrm{Cx}$ protein along the plasma membrane at cell-cell contacts. Regulation of this part of GJs positively influenced OXA cytotoxicity. Using RNA interference, only specific inhibition of $\mathrm{Cx} 26$ but not $\mathrm{Cx} 32$ or $\mathrm{Cx} 43$ reduced OXA cytotoxicity. Conversely, $\mathrm{Cx} 26$ overexpression by transfection
\end{abstract}

Correspondence to: Dr Qiong Wu, Department of Medical Oncology, The First Affiliated Hospital of Bengbu Medical College, Bengbu, Anhui 233004, P.R. China

E-mail: qiongwu68@outlook.com

Abbreviations: $18-\alpha-G A, 18-\alpha-$ glycyrrhetinic acid; ATRA, all-trans retinoid acid; CIS, cisplatin; $\mathrm{Cx}$, connexin; GJ, gap junction; HCC, hepatocellular carcinoma; OXA, oxaliplatin

Key words: hepatocellular carcinoma, oxalipaltin, chemosensitivity, gap junction, connexin 26 of Cx26 plasmid DNA enhanced OXA cytotoxicity. This study demonstrated that during hepatocarcinogenesis, the reduced expression and internalization of Cx proteins impaired the GJ function, which further attenuated OXA cytotoxicity. Impaired GJ function may contribute to low intrinsic chemosensitivity of HCC cells to OXA, mediated by $\mathrm{Cx} 26$.

\section{Introduction}

Hepatocellular carcinoma (HCC) is a significant cause of death worldwide. It has an insidious onset, with a high degree of malignancy and very poor prognosis. Palliative chemotherapy is one of the most important treatments for locally advanced and metastatic HCCs, which are unresectable. In recent years, the third-generation platinum compounds have been proposed as potential active for HCC $(1,2)$. The positive results from the randomized phase III clinical trial EACH (3), further support the role of systemic oxaliplatin (OXA)-based regimen in advanced HCC (4). However, clinical benefits induce by OXA are limited (5), and HCC is traditionally believed to be insensitive to chemotherapy (6). The mechanisms underlying low chemotherapeutic response of HCC are poorly understood.

Gap junction (GJ), a protein channel connecting two adjacent cells, is composed of special proteins called connexins (Cxs). Distinct Cx subtype is named based on its molecular weight. Six Cxs form a hemi-channel (also called connexon) docking with its counterpart in the neighboring cell to form an integral GJ channel. These channels mediate direct intercellular molecular signaling, allowing intercellular exchange of signaling molecules such as inorganic ions, second messengers and other regulatory substances. The intercellular molecular exchange mediates various cellular events, including metabolism, homeostasis, cell proliferation and differentiation, and carcinogenesis $(7,8)$.

Evidence demonstrates that cytotoxicity of multiple drugs is amplified via bystander effect (BE), which is partially mediated by cell-cell communication mediated by GJs (9). It is noteworthy that $\mathrm{GJ}$ increases the cytotoxicity of platinum drugs. Jensen et al (10) found that cisplatin (CIS)-induced apoptosis produced death signals, which are transmitted to neighboring cells via GJs. CIS toxicity in bladder cancer cells was enhanced 
after GJ was upregulated by Cx26 transfection (11), and also strengthened in breast cancer cells by quinolines (GJ enhancer) in vivo or in vitro (12). Supersensitivity of spinal astrocytes to OXA was accompanied by the upregulation of Cx43 and GJ (13). Association of chemo-resistant phenotypes with GJs in a three-dimensional culture model of soft sarcoma has also been documented recently (14).

According to the BE mechanism, the efficacy of platinum drugs positively correlated with GJ level in tumor cells. However, tumor cells (including hepatic) were often accompanied by a decline or loss of GJ (15-17). For instance, normal liver tissue is abundant in GJs, mainly expressing Cx26, Cx32 and Cx43 $(18,19)$. In rat hepatic tumorigenesis induced by oncogenic drugs, GJ and its composed Cx were downregulated (20). The expression of Cx32 and Cx43 in HCC tissues was found to be lower than in normal hepatic tissues (21). Aberrant expression and localization of Cx32 was observed during HCC development and progression (22). Based on these findings, we inferred that when GJ function decreased or was lacking in HCC, cytotoxic signal was not transmitted to adjacent cells, leading to decreased $\mathrm{BE}$, and low chemosensitivity of $\mathrm{HCC}$ cells to cytotoxic drugs including OXA. Additionally, the $\mathrm{Cx}$ isoform determines the function of GJ channel and also the type of signal transduction $(23,24)$. Therefore, our study systematically investigated the functional status of $\mathrm{Cx}$ and GJs in HCC at both histologic and cytologic levels, and further focused on the effect of GJs on OXA cytotoxicity in vitro. The effective GJ components participated in the process were also explored. The study may offer new insight into the mechanisms of low response of HCC to chemotherapeutic drugs, and also provide novel potential approaches and strategies to enhance OXA chemosensitivity in liver cancer.

\section{Materials and methods}

Materials. SP kits were obtained from Fuzhou Maixin Biotech. Co., Ltd (Fujian, China). OXA, 18- $\alpha$-glycyrrhetinic acid (18- $\alpha-\mathrm{GA})$, all-trans retinoid acid (ATRA), dimethyl sulfoxide (DMSO), 3-(4,5-dimethylthiazol-2-yl)-2,5-diphenyltetrazolium bromide (MTT), anti-Cx32 and anti-Cx43 mouse IgG were purchased from Sigma (St. Louis, MO, USA). DMEM, fetal bovine serum, TRIzol, Lipofectamine ${ }^{\mathrm{TM}}$ 2000, DAPI, DiI-CM, calcein-AM, and anti-Cx26 mouse IgG were procured from Invitrogen (Carlsbad, CA, USA). HPR and FITC-labeled goat anti-mouse secondary antibody were obtained from Amersham Biosciences Corp. (Piscataway, NJ, USA). All other reagents were from Sigma unless stated otherwise.

Cell line and cell culture. Human normal liver cell line LO2 was obtained from KeyGEN BioTECH (Nanjing, China). Human HCC cell line SMMC-7721 was provided by Chinese Type Culture Collection (Shanghai, China). Both cell lines were grown at $37^{\circ} \mathrm{C}$ in a humidified atmosphere containing $5 \%(\mathrm{v} / \mathrm{v})$ $\mathrm{CO}_{2}$ in DMEM supplemented with $10 \%$ fetal bovine serum, $100 \mathrm{U} / \mathrm{ml}$ streptomycin and $100 \mathrm{mg} / \mathrm{ml}$ penicillin. Cells in the exponential phase of growth were selected for experiment.

\section{Immunohistochemistry}

Samples. Without any preoperative treatment, 76 archived HCC paraffin samples were collected from patients following resection at the First Affiliated Hospital of Bengbu Medical College from January 2008 to December 2013. Twenty normal liver tissues obtained via hepatic resection following hepatic trauma or accidental death (healthy prior to death) served as controls. For the HCC samples, 61 were male and 15 were female, with a median age of 50 years old (range: 22-76 years). The diagnosis was confirmed histologically in all cases. Histology grade was based on the criteria proposed by Edmondson and Steiner. Histological grade I-II accounted for $63 \%$ (48 samples), and grade III-IV accounted for $37 \%$ (28 samples). The nontumorous liver adjacent to tumor showed cirrhosis or chronic hepatitis in $60(79 \%)$ samples. Staging at the time of diagnosis was based on the tumor-node-metastasis (TNM) classification. Tumors of stage I-II accounted for $71 \%$ (54 samples), and tumors of stage III-IV accounted for $29 \%$ (22 samples). Tumor size and lymph node status were evaluated separately.

Immunohistochemical staining. Detail experimental procedures were described in our previous studies $(25,26)$. Specific procedures were strictly performed according to the manufacturer's instructions. PBS instead of primary antibody was used as the negative control. Positive staining and cellular localization were observed and photographed with an optical microscope.

Immunohistochemical evaluation. Cx staining was detected on the membrane or in the cytoplasm. Yellow particles in cells were considered positive. We calculated 500 tumor or normal liver cells for every section under high magnification. The distribution of Cx-positive spots was considered as 'internalization' if the spots were removed (or partially removed) from the cell surface and detected in the cytoplasm, and the internalization rate was calculated as follows: (The number of $\mathrm{Cx}$ internalization cases/the total number of $\mathrm{Cx}$ positive expression cases) $\mathrm{x} 100 \%$.

RNA isolation and reverse transcriptase-polymerase chain reaction $(R T-P C R)$. Total RNA was extracted using TRIzol reagent according to the manufacturer's instructions. cDNA was synthesized by reverse transcription with a random primer. The specific Cx upstream and downstream primers were added to the reverse transcription cocktail to perform PCR. The following primers were used: for human Cx26, 5'-GCT GCAAGAACGTGTGCTAC-3' (upstream), 5'-TGGGTT TTGATCTCCTCGAT-3' (downstream), product size 196 bp; for human Cx32, 5'-TCCCTGCAGCTCATCCTAGT-3' (upstream), 5'-CCCTGAGATGTGGACCTTGT-3' (downstream), product size $156 \mathrm{bp}$; for human Cx43, 5'-GGTCTGA GTGCCTGAACTTGCCT-3' (upstream), 5'-AGCCACAC CTTCCCTCCAGCA-3' (downstream), product size $184 \mathrm{bp}$. Human $\beta$-actin was used as an internal reference, with the primer sequence 5'-TCCTCCTGAGCGCAAGTACTC-3' (upstream), and 5'-GCATTTGCGGTGGACGAT-3' (downstream), and product size $130 \mathrm{bp}$. The reaction volume of PCR was $20 \mu \mathrm{l}$. PCR was initiated at $94^{\circ} \mathrm{C}$ for $3 \mathrm{~min}$ followed by 30 cycles consisting of $45 \mathrm{sec}$ at $94^{\circ} \mathrm{C}, 45 \mathrm{sec}$ at $55^{\circ} \mathrm{C}$, and $45 \mathrm{sec}$ at $72^{\circ} \mathrm{C}$, with the final cycle extended to $10 \mathrm{~min}$ at $72^{\circ} \mathrm{C}$, followed by termination at $4^{\circ} \mathrm{C}$. PCR amplicons $(5 \mu \mathrm{l})$ were analyzed on an ethidium bromide-stained $1.5 \%$ agarose gel. 
Table I. siRNA sequences for human Cx26, Cx32 and Cx43.

Sequence

\begin{tabular}{|c|c|c|c|}
\hline Genbank ID & Gene & Sense $\left(5^{\prime}-3^{\prime}\right)$ & Antisense (5'-3') \\
\hline \multirow[t]{3}{*}{ NM_004004.5 } & Human Cx26 & GAGGCUCAGAUUGUAAUAUTT & AUAUUACAAUCUGAGCCUCTT \\
\hline & & CCACGUUAAAGGUGAACAUTT & AUGUUCACCUUUAACGUGGTT \\
\hline & & CCCAGUUGUUAGAUUAAGATT & UCUUAAUCUAACAACUGGGTT \\
\hline \multirow[t]{3}{*}{ NM_001097642.2 } & Human Cx32 & GCUCCCUGAAAGACAUACUTT & AGUAUGUCUUUCAGGGAGCTT \\
\hline & & GCCGUCUUCAUGUAUGUCUTT & AGACAUACAUGAAGACGGCTT \\
\hline & & GCAACACAUAGAGAAGAAATT & UUUCUUCUCUAUGUGUUGCTT \\
\hline \multirow[t]{3}{*}{ NM_000165.4 } & Human $\mathrm{Cx} 43$ & GGCCUUGAAUAUCAUUGAATT & UUCAAUGAUAUUCAAGGCCTT \\
\hline & & GCCGCAAUUACAACAAGCATT & UGCUUGUUGUAAUUGCGGCTT \\
\hline & & GGAAGCACCAUCUCUAACUTT & AGUUAGAGAUGGUGCUUCCTT \\
\hline
\end{tabular}

Western blotting. LO2 and SMMC-7721 cells were harvested, centrifuged $\left(12000 \mathrm{x} \mathrm{g} / \mathrm{min}\right.$ at $4^{\circ} \mathrm{C}$ for $\left.30 \mathrm{~min}\right)$, and supernatants were obtained. Protein concentration was determined using a DC protein assay kit (Bio-Rad Co., Hercules, CA, USA). Samples $(50 \mu \mathrm{g})$ from cells were transferred to SDS-PAGE, followed by electrophoresis and blotting. Monoclonal antibodies against Cxs (Cx26-1:1000; Cx32-1:2000; Cx43-1:4000) or $\beta$-actin $(1: 10,000)$ were used. The immunoreactive bands were visualized using Amersham ECL ${ }^{\mathrm{TM}}$ Plus Western Blotting Detection kit (GE Healthcare, Piscataway, NJ, USA).

Immunofluorescence. Cells in exponential growth phase were collected, and fixed with $0.1 \%$ Triton X-100-4\% paraformaldehyde for $30 \mathrm{~min}$ at room temperature. Coverslips were blocked with $2 \%$ BSA in PBS and probed with the primary antibodies (Cx26-1:200; Cx32-1:100; Cx43-1:200; diluted in $2 \% \mathrm{BSA}$ ) overnight at $4^{\circ} \mathrm{C}$. A secondary antibody FITC anti-mouse IgG (1:200, diluted in 2\% BSA) was added, and incubated for $2 \mathrm{~h}$ in the dark, at room temperature. Nuclear staining was performed with DAPI at $37^{\circ} \mathrm{C}$ for $5 \mathrm{~min}$. After rinsing, the coverslips were mounted on slides, and the cells were observed and photographed under a fluorescence microscope (Olympus).

Determination of GJ function: 'Parachute' dye-coupling assay. 'Parachute' dye-coupling protocols were described in our previous studies (27,28). Briefly, LO2 and SMMC-7721 cells were grown to $80 \%-85 \%$ confluence. Donor cells from one well were incubated with a freshly made solution of $5 \mu \mathrm{M}$ calcein-AM and $2.5 \mu \mathrm{M}$ CM-DiI in growth medium at $37^{\circ} \mathrm{C}$ for $30 \mathrm{~min}$. Calcein-AM was converted intracellularly into the small GJ-permeable dye calcein, while CM-DiI was too large to spread to coupled cells through GJs. Unincorporated dye was removed by three gentle washes with PBS. The donor cells were then trypsinized and seeded onto the receiver cells at a density of $500-800$ cells $/ \mathrm{ml}$, and cultured at $37^{\circ} \mathrm{C}$ for $4 \mathrm{~h}$. The small molecule calcein (green fluorescence) entered adjacent recipient cells through GJs when stable GJs were formed. The index of GJ function was defined by counting the number of recipient cells containing calcein around one donor cell under fluorescence microscope.
MTT assay. OXA toxicity was assessed by MTT assay. SMMC-7721 cells were seeded at a density of $8 \times 10^{3} /$ well into 96-well plates for $24 \mathrm{~h}$. OXA of different concentrations were then added for the indicated time periods. MTT $(5 \mathrm{mg} / \mathrm{ml})$ was added to each well, and dishes were cultured at $37^{\circ} \mathrm{C}$ for $4 \mathrm{~h}$. The medium containing MTT was then removed, and $150 \mu \mathrm{l}$ DMSO was added into each well to fully dissolve formazan crystals in the viable cells. The absorbance at $490 \mathrm{~nm}$ of each well was read using a microplate ELISA reader (MRX II; Dynex Technologies, Chantilly, VA, USA). Cell viability was calculated as follows: (OD of experimental group - OD of blank group) / (OD of control group - OD of blank group).

Modulation of GJ function. SMMC-7721 cells were seeded at high $\left(8 \times 10^{3} /\right.$ well $)$ and low $\left(0.5 \times 10^{3} /\right.$ well $)$ density into 96 -well plates to obtain GJ-formed and non-GJ formed cells, corresponding to conditions in which junctional channel formation was permitted or not, respectively (10). After cells at high density were grown to $80-85 \%$ confluence, the cells under both culture conditions were then exposed to a defined dose of OXA for $24 \mathrm{~h}$, to enable the effect of GJ presence on OXA toxicity to be observed. The changes in OXA cytotoxicity were also investigated in high density-cultured cells pretreated with GJ tool drugs, ATRA $(10 \mu \mathrm{M})$ and $18-\alpha-\mathrm{GA}(5 \mu \mathrm{M})$, for $24 \mathrm{~h}$ and $1 \mathrm{~h}$, respectively.

Specific regulation of $C x$ expression by RNA interference and $C x 26$ overexpression. The siRNA fragments of different Cxs were synthesized and provided by Shanghai GenePharma Co., Ltd. (Shanghai, China). Three specific interfering sequences for each Cx gene were synthesized as listed in Table I. Cx26 was overexpressed in SMMC-7721 cells using a pEX-2/hCx26 vector (Shanghai GenePharma Co.). Negative control siRNA (NC in the figures) and empty vector negative control were also maintained. Transfection into SMMC-7721 cells was carried out using Lipofectamine 2000 according to the manufacturer's instructions. Knockdown and upregulation of $\mathrm{Cx}$ expression were confirmed by western blotting.

Statistical analysis. Results were analyzed with SPSS version 17.0 software (Chicago, IL, USA). Differences between two 
Table II. Expression of Cx26, Cx32 and Cx43 in human normal liver and HCC tissues.

\begin{tabular}{|c|c|c|c|c|c|c|c|}
\hline \multirow[b]{2}{*}{ Group } & \multirow[b]{2}{*}{$\mathrm{n}$} & \multicolumn{2}{|c|}{$\mathrm{Cx} 26$} & \multicolumn{2}{|c|}{$\mathrm{Cx} 32$} & \multicolumn{2}{|c|}{$\mathrm{Cx} 43$} \\
\hline & & - & + & - & + & - & + \\
\hline Normal liver & 20 & 0 & 20 & 0 & 20 & 2 & 18 \\
\hline $\mathrm{HCC}$ & 76 & 40 & 36 & 43 & 33 & 30 & 46 \\
\hline$\chi^{2}$-value & & \multicolumn{2}{|c|}{18.045} & \multicolumn{2}{|c|}{20.497} & \multicolumn{2}{|c|}{6.189} \\
\hline p-value & & \multicolumn{2}{|c|}{0.000} & \multicolumn{2}{|c|}{0.000} & \multicolumn{2}{|c|}{0.015} \\
\hline
\end{tabular}

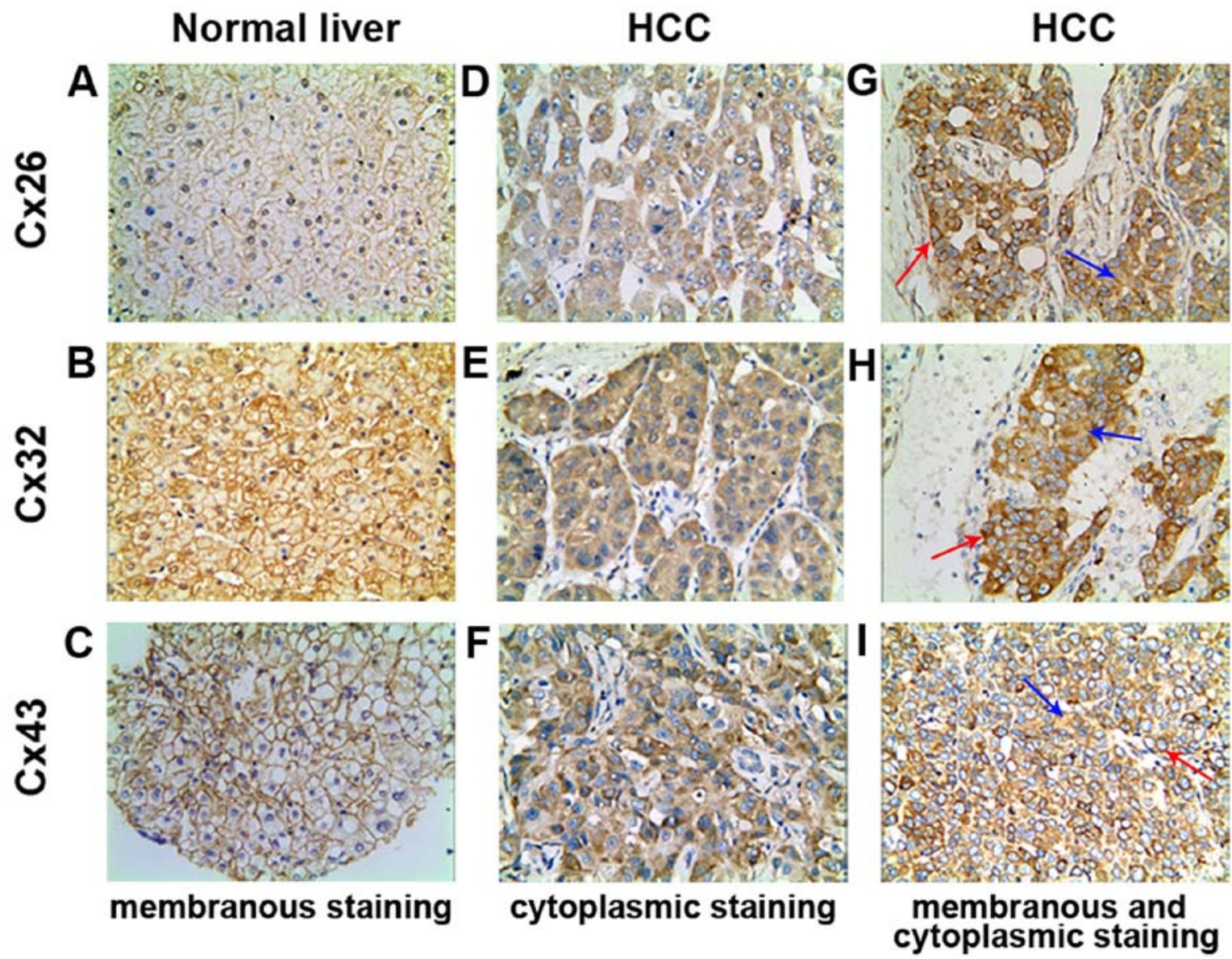

Figure 1. Immunohistochemical analyses of Cx26, Cx32 and Cx43 in sections of human normal liver and HCC tissues. (A-C) Normal liver cells showing extensive membranous staining for the three Cx proteins. (D-F) Cytoplasmic positive staining for Cxs in HCC tissues. (G-I) Both membranous (marked by red arrow) and cytoplasmic (marked by blue arrow) expression of Cxs in certain HCC cases. Representative immunohistochemical examples of staining are shown (original magnification, $\mathrm{x} 400$ ).

groups in immunohistochemistry experiments were evaluated by $\chi^{2}$ test and Fisher's exact test where appropriate. Numerical data are presented as means \pm SEM and compared with unpaired Student's t test using Sigmaplot 10.0 software (Jandel Scientific, San Rafael, CA, USA). Differences at $\mathrm{p}<0.05$ were considered significant.

\section{Results}

Cx expression in human normal and HCC liver tissues. As shown in Table II, Cx26 and Cx32 was $100 \%$ and Cx43 showed $90.00 \%$ positive expression in normal liver tissues.
However, the positive rate for the three Cxs was significantly reduced to $47.37,43.42$ and $60.53 \%$ in $\mathrm{HCC}$ tissues, respectively $\left(\chi^{2}=18.045, p=0.000 ; \chi^{2}=20.497, p=0.000 ; \chi^{2}=6.189\right.$, $\mathrm{p}=0.015)$. In $\mathrm{Cx}$ localization, while the positive particles were distributed mainly linearly on membrane in normal liver tissues (Fig. 1A-C), in HCC tissues Cxs stained positive mostly in the cytoplasm (Fig. 1D-F), and occasionally on the membrane of cancer cells, concurrently in certain cases (Fig. 1G-I). The phenomenon of Cx removal from membrane to cytoplasm is known as 'internalization'. The internalization rates of the three $\mathrm{Cx}$ proteins in HCC group were $100 \%$ and statistically significant compared with the normal liver tissue 
A

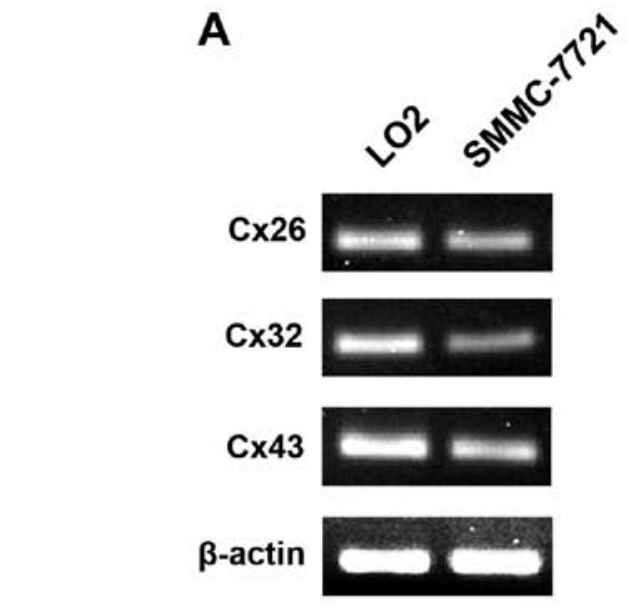

C
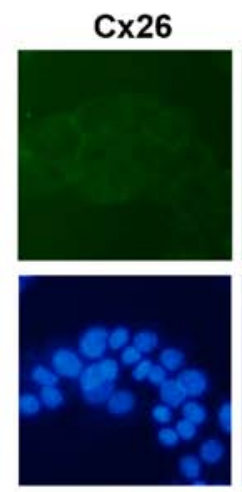

D

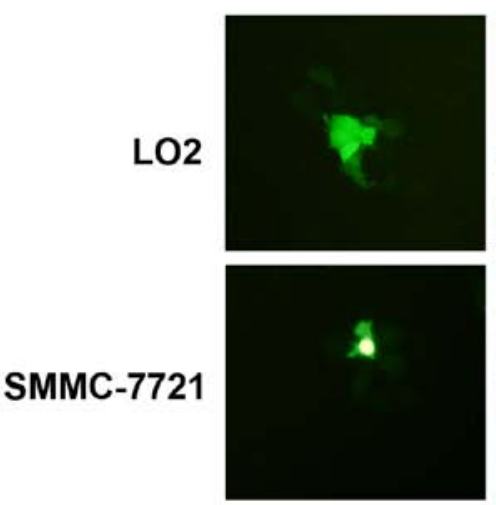

LO2
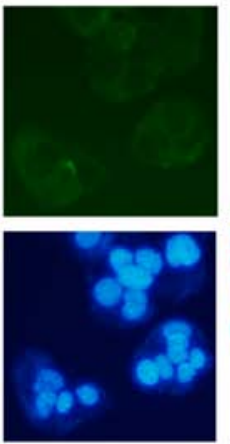

B

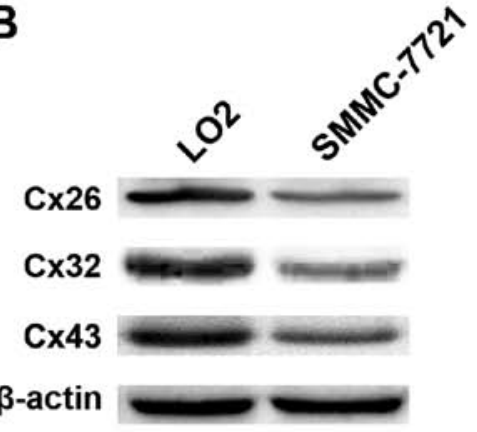

$\beta$-actin
SMMC-7721
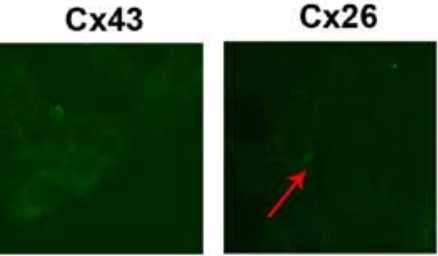

Cx32
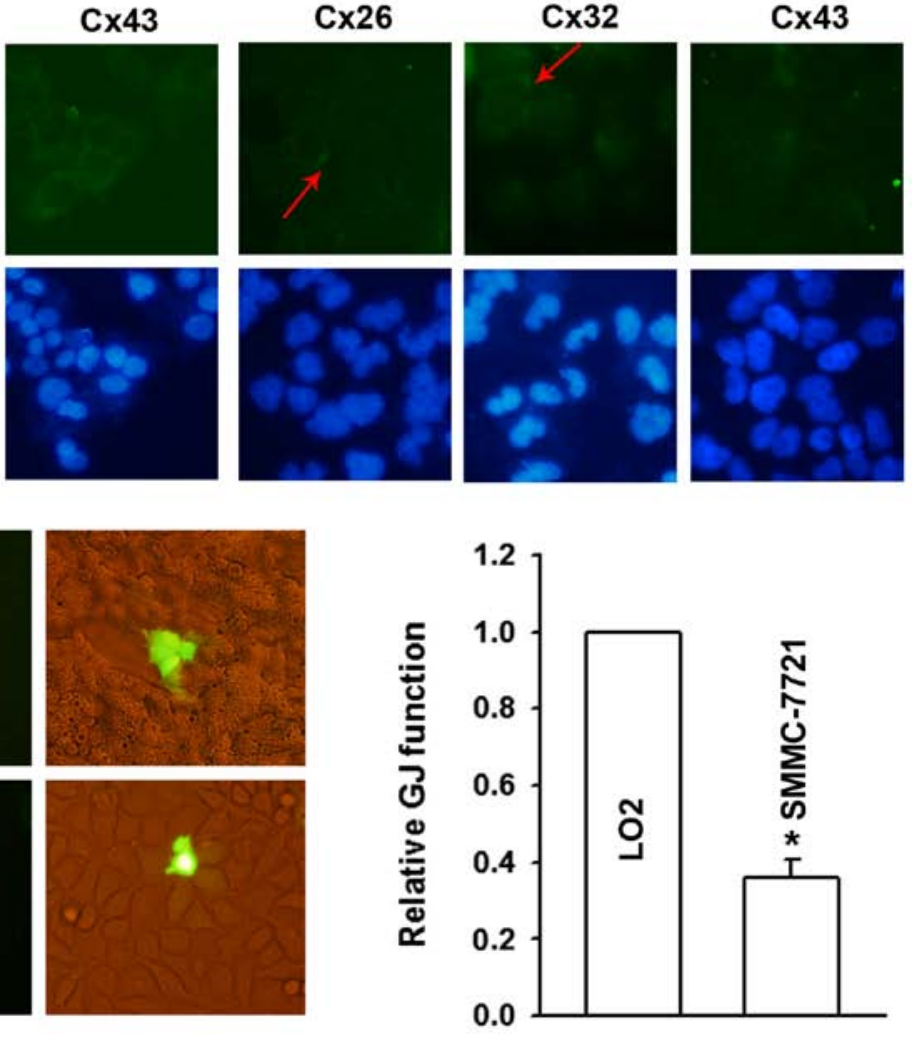

Figure 2. Detection of $\mathrm{Cx} 26, \mathrm{Cx} 32$ and $\mathrm{Cx} 43$ expression and GJ status in human normal liver cell line LO2 and hepatoma cell line SMMC-7721. (A and B) Decreased mRNA and protein expression of Cx26, Cx32 and Cx43 in SMMC-7721 cells compared with those in LO2 cells, as shown by agarose gel electrophoresis of RT-PCR products and western blotting, respectively. (C) Immunofluorescent staining of Cx26, Cx32 and Cx43 proteins in vitro. LO2 cells showed mainly membranous staining for Cxs, while diffuse cytoplasmic staining for Cxs in SMMC-7721 cells was observed. Only a partial Cx26 and Cx32 expression on SMMC-7721 cell membrane was concurrently detected (marked by red arrow), and Cx43 was only observed in the cytoplasm of SMMC-7721 cells (x200). (D) GJ activity of SMMC-7721 cells was markedly reduced compared with that of LO2 cells, as evidenced by parachute dye coupling assay (x200). Data represent the mean \pm SEM of three independent experiments. ${ }^{*}<<0.05$ vs. LO2 group.

$\operatorname{group}\left(\chi^{2}=43.938, \mathrm{p}=0.000 ; \chi^{2}=31.392, \mathrm{p}=0.000 ; \chi^{2}=41.358\right.$, $\mathrm{p}=0.000$, Table III).

Cx expression and GJ function in human normal liver LO2 and hepatoma SMMC-7721 cells. The reduced levels and cytoplasmic localization of $\mathrm{Cx}$ protein suggested a decreased GJ function in HCC carcinogenesis. To further validate the histologic results of the Asian population, two Asian-derived human cell lines including the normal liver cell line LO2 and HCC cell line SMMC-7721 were used in vitro. The RT-PCR and western blot results revealed a positive expression of $\mathrm{Cx} 26$, Cx32 and Cx43 at both mRNA and protein levels. Compared with LO2 cells, the expression of Cxs was markedly reduced in SMMC-7721 cells (Fig. 2A and B). Immunofluorescence analysis revealed a clear membranous localization of the three Cxs in $\mathrm{LO} 2$ cells. While in SMMC-7721 cells, Cx26 and Cx32 were detected mainly in the cytoplasm and only a partial expression on membrane; and for $\mathrm{Cx} 43$ only cytoplasmic staining was observed (Fig. 2C). Thus cytologic and histologic results were highly consistent. Subsequent 'parachute' dye-coupling assay 
A

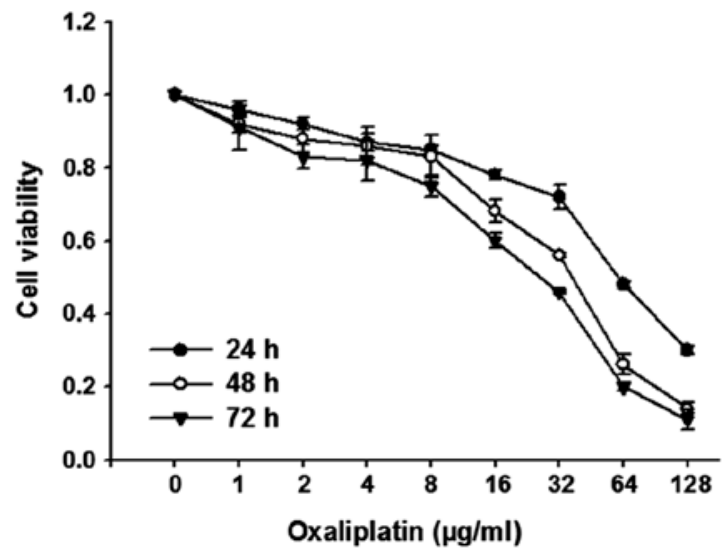

B

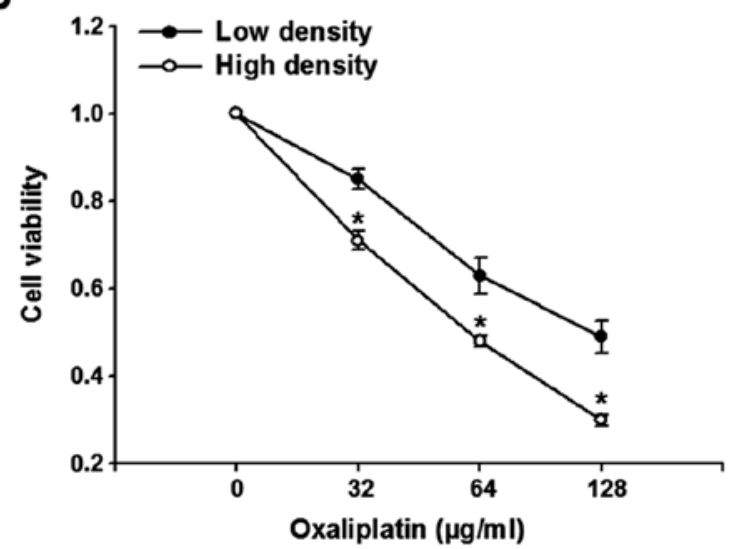

C

SMMC-7721
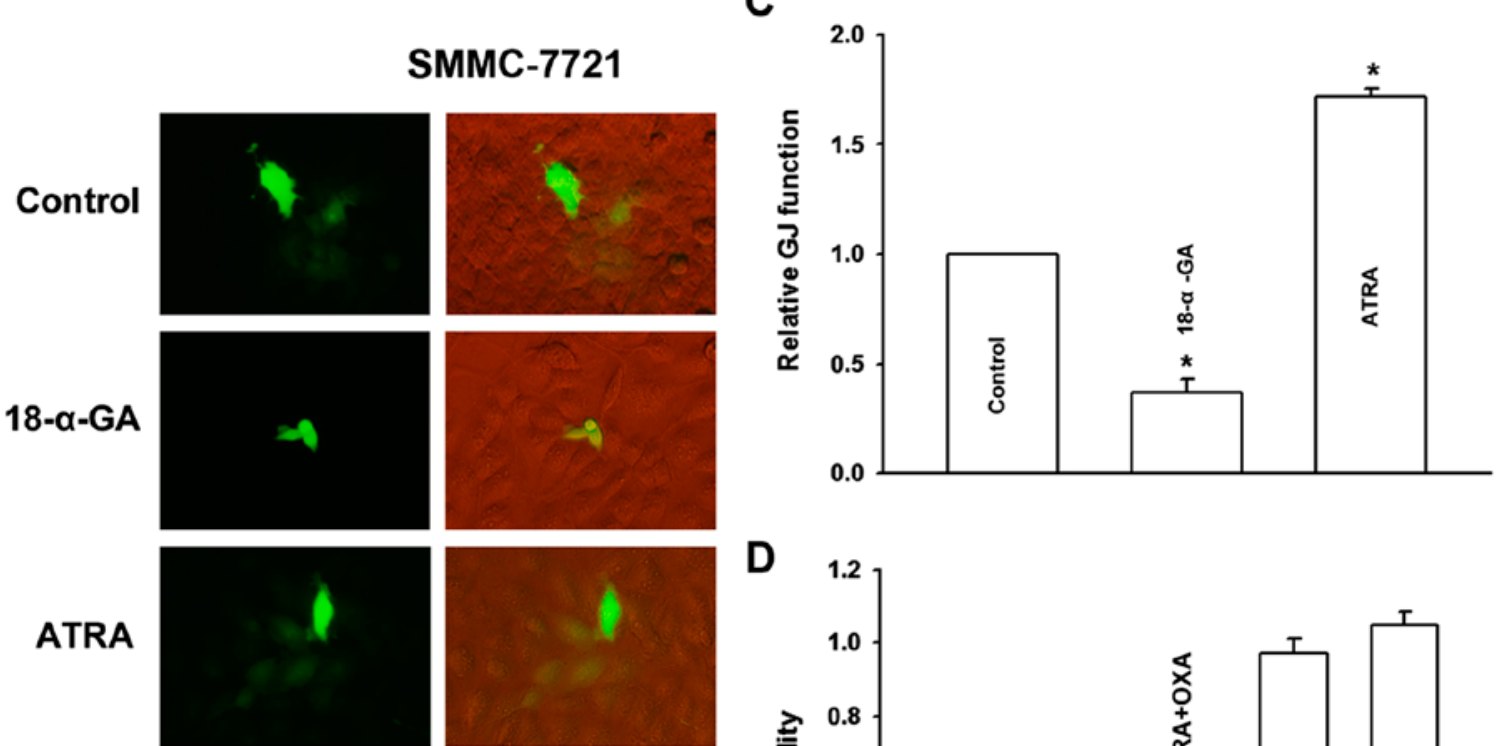

ATRA

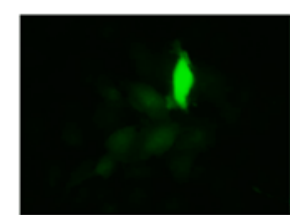

\section{D}

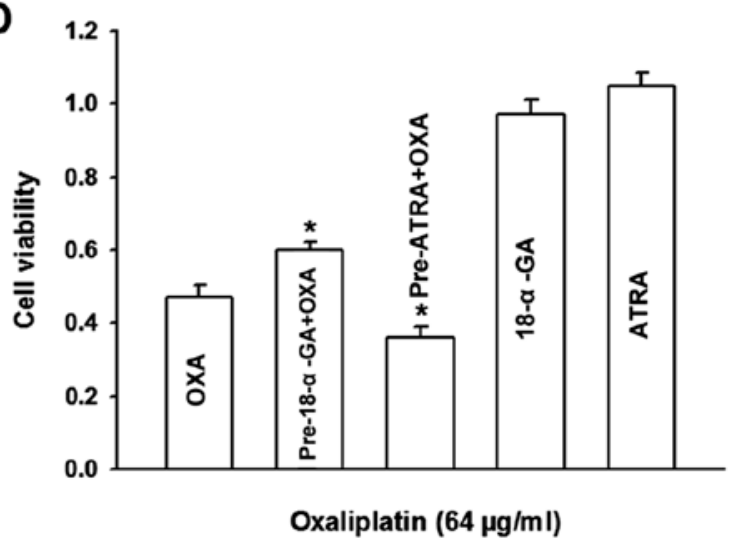

Figure 3. GJ modulates OXA cytotoxcity in SMMC-7721 cells. (A) Growth inhibition of SMMC-7721 cells by a range of OXA concentrations for the indicated time periods. (B) Cell viability of SMMC-7721 cells incubated for $24 \mathrm{~h}$ with increasing doses of OXA at low and high cell density. Culture at high density enhanced OXA toxicity compared with that at low density. (C) Fluorescence images showed the degree of dye coupling by the parachute assay. 18- $\alpha$-GA treatment $(5 \mu \mathrm{M})$ for $1 \mathrm{~h}$ decreased GJ function while $10 \mu \mathrm{M}$ ATRA treatment for $24 \mathrm{~h}$ increased GJ function in SMMC-7721 cells. (D) Cell viability of SMMC-7721 cells incubated with $64 \mu \mathrm{g} / \mathrm{ml}$ OXA for $24 \mathrm{~h}$ with or without $18-\alpha$-GA or ATRA pretreatment at high cell density. Data represent the mean \pm SEM of 3 to 6 independent experiments. ${ }^{*}$ p $<0.05$ vs. low cell density group (B); ${ }^{*}$ p $<0.05$ vs. control (C); ${ }^{*}$ p $<0.05$ vs. OXA treatment alone (D).

in vitro revealed that GJ was abundant in $\mathrm{LO} 2$ cells, and was attenuated to $36 \%$ in SMMC-7721 cells (Fig. 2D).

GJ modulates OXA cytotoxicity in SMMC-7721 cells. As shown in Fig. 3A, results of MTT indicated that cell viability of SMMC-7721 cells decreased with increase in OXA concentration and treatment time. The effects of 32, 64 and $128 \mu \mathrm{g} / \mathrm{ml}$ dose groups were significant, and the inhibition rates for $24 \mathrm{~h}$ were 28,52 and $70 \%$, respectively. In the experiments involving high-density and low-density cell seeding, we found that OXA cytotoxicity of high-density cultures was substantially greater than that of low-density cultures $(\mathrm{p}<0.05$, Fig. 3B). The formation of GJs is just one of the several potential differences between low and high density cultures, and therefore, GJ coupling was further manipulated in the cultures by chemical drugs.

18- $\alpha$-GA, recognized as a GJ channel inhibitor $(29,30)$, and ATRA as an enhancer of reinforced Cx expression in various tumor cells $(31,32)$, have been widely used in the GJ analysis. We then observed the alteration of GJ function in SMMC-7721 cells by these two drugs. As shown in Fig. 3C, 18- $\alpha$-GA $(5 \mu \mathrm{M})$ treatment for $1 \mathrm{~h}$ significantly inhibited GJ 
A

CX26

$\beta$-actin

$\mathrm{Cx} 32$

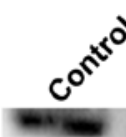

$+$

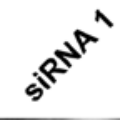

s+tit
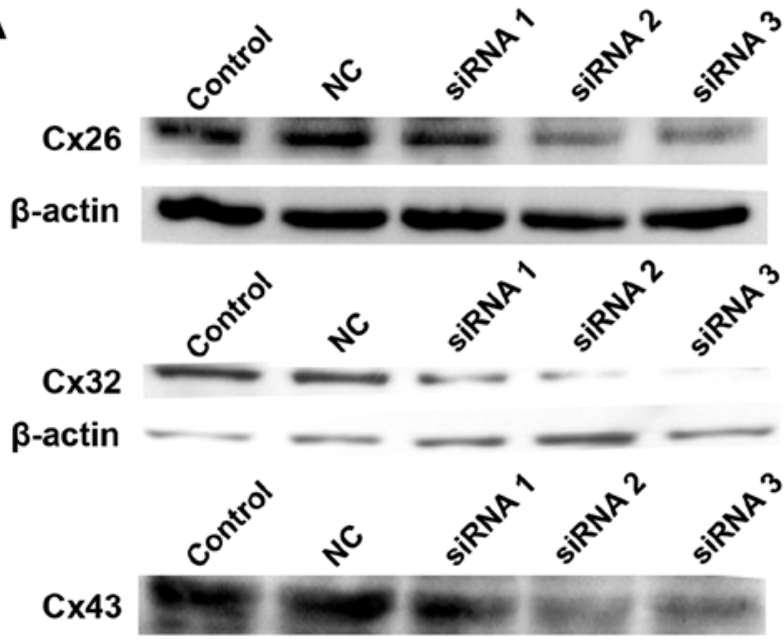

$\beta$-actin

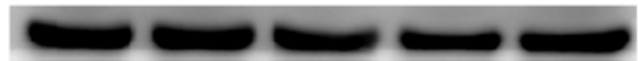

B

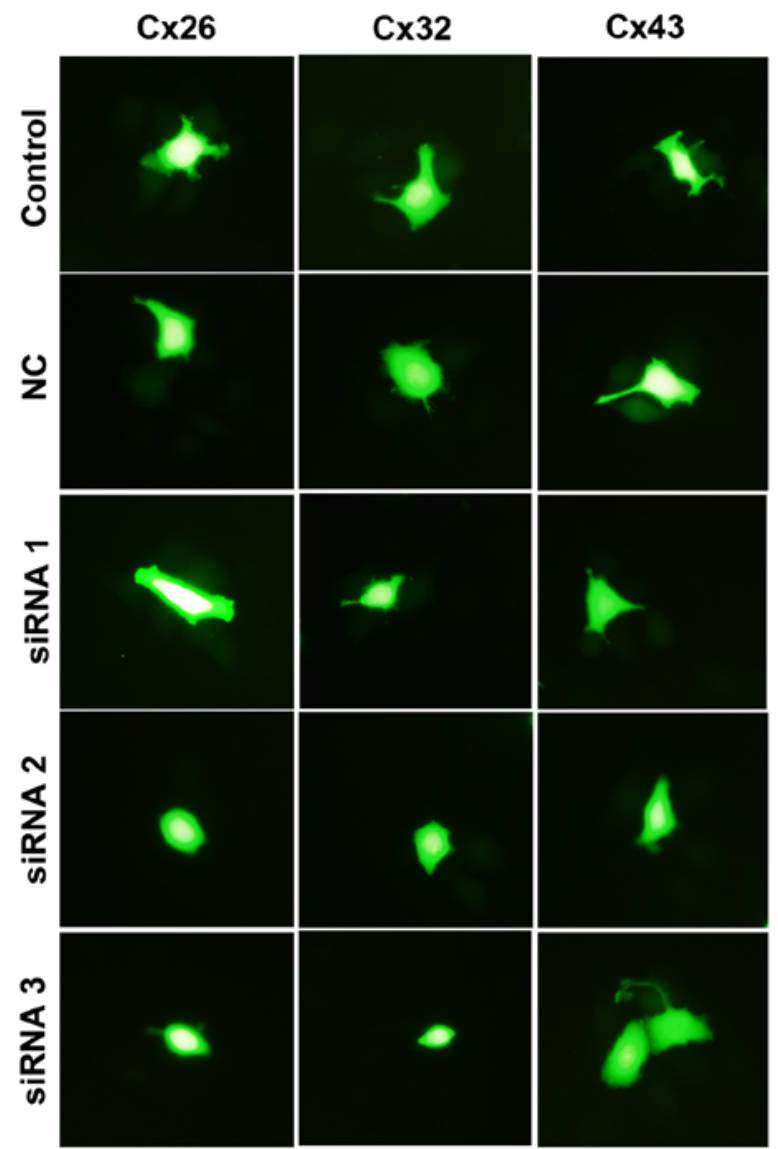

C

Cx26

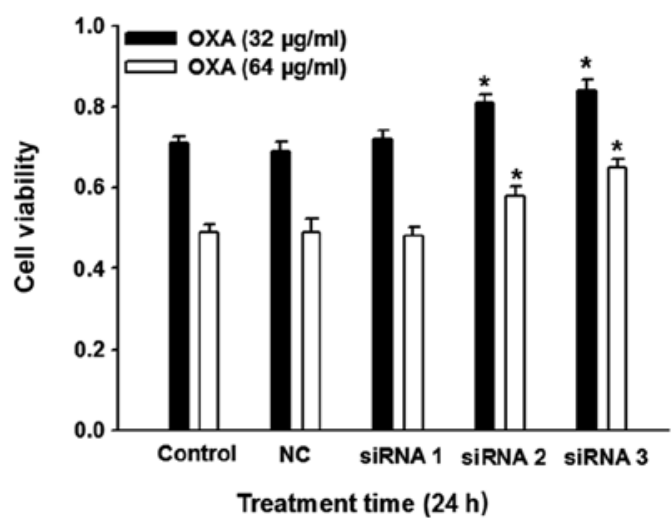

Cx32

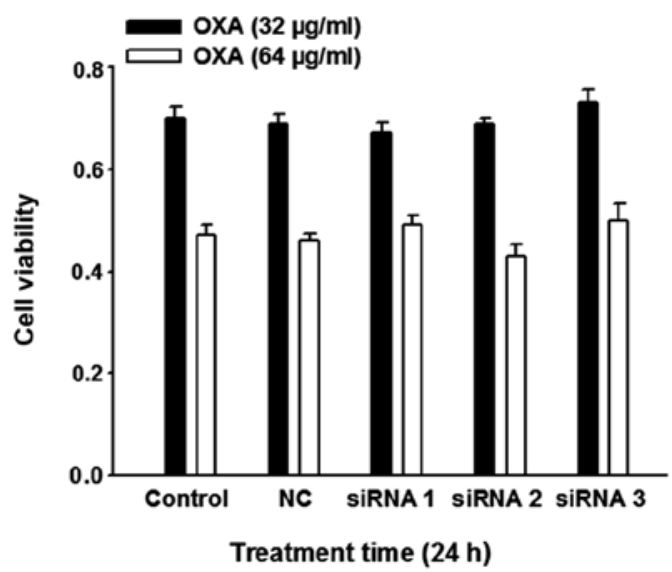

Cx43

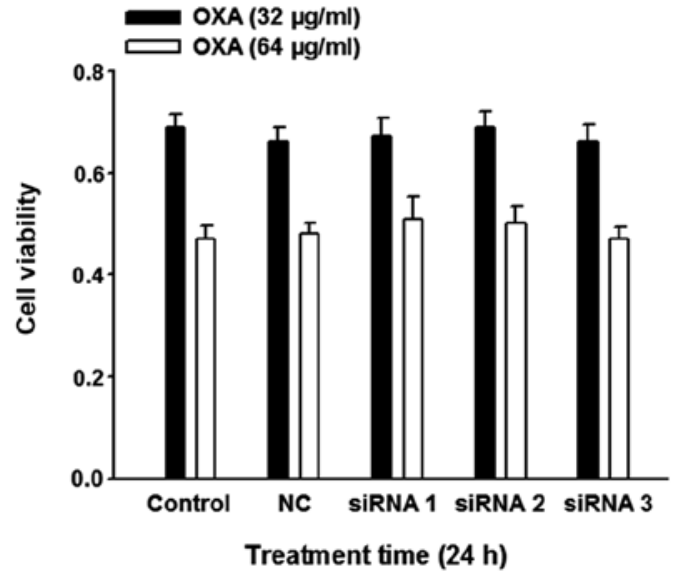

Figure 4. Effect of siRNA-mediated knockdown on Cx expression, GJ function and OXA cytotoxcity in SMMC-7721 cells. (A) Western blot of siRNA-mediated knockdown of $\mathrm{Cx} 26, \mathrm{Cx} 32$ and $\mathrm{Cx} 43$ expression. (B) Fluorescence images showed the degree of dye coupling by the parachute assay. Cells in which Cx expression was knocked down by siRNA targeting $\mathrm{Cx} 26$ or $\mathrm{Cx} 32$ showed lower dye transfer than control cells (no siRNA) and cells transfected with negative control siRNA (NC group). Negative control, siRNA: cells transiently transfected with synthetic negative control siRNA or siRNA targeting Cx26, Cx32 and Cx43, respectively. Representative images are shown (original magnification x200). (C) High-density cultured cell viability after $24 \mathrm{~h}$ incubation with both $32 \mu \mathrm{g} / \mathrm{ml}$ and $64 \mu \mathrm{g} / \mathrm{ml}$ OXA of control, negative control (NC) and Cx knockdown. Data represent the mean \pm SEM of four independent experiments. ${ }^{*} \mathrm{p}<0.05 \mathrm{vs.} \mathrm{control}$.

function by about $63 \%$; conversely, ATRA $(10 \mu \mathrm{M})$ treatment for $24 \mathrm{~h}$ markedly strengthened GJ function by about $72 \%$. Subsequent studies revealed that $18-\alpha-\mathrm{GA}(5 \mu \mathrm{M})$ and ATRA $(10 \mu \mathrm{M})$ alone had no obvious effect on SMMC-7721 cell growth. However, upon pretreatment with $18-\alpha-\mathrm{GA}$ for
$1 \mathrm{~h}$ to inhibit GJ function, OXA toxicity was reduced. On the contrary, upon pretreatment with ATRA for $24 \mathrm{~h}$ to increase GJ function, OXA toxicity was increased ( $\mathrm{p}<0.05$, Fig. 3D). These results suggested a potential role of GJ in modulating OXA cytotoxicity in SMMC-7721 cells. 
A
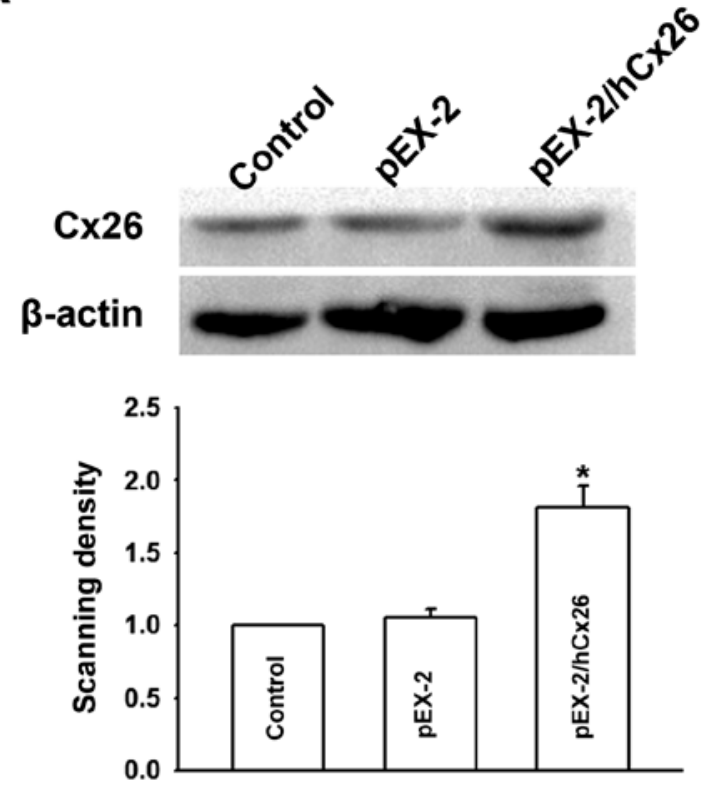

C

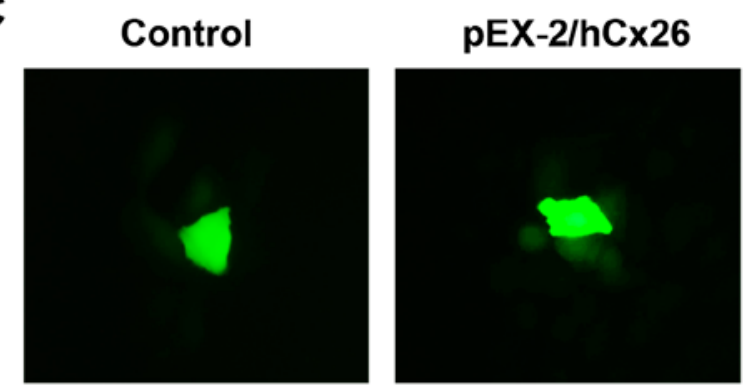

B Cx26

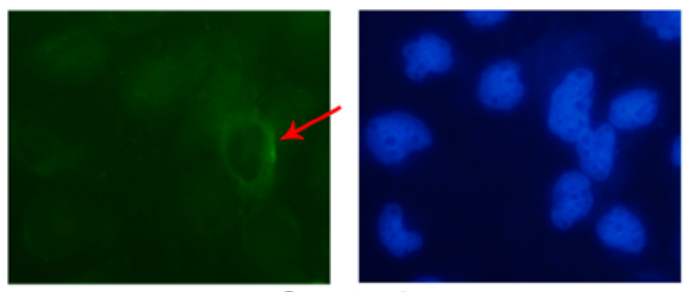

Control

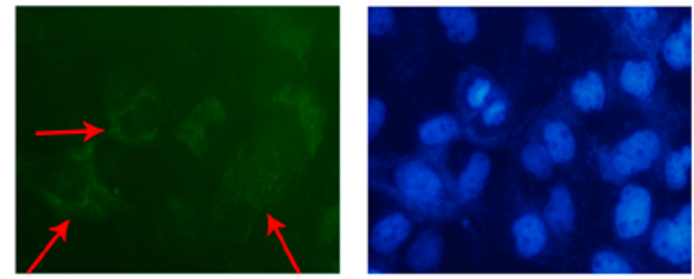

pEX-2/hCx26

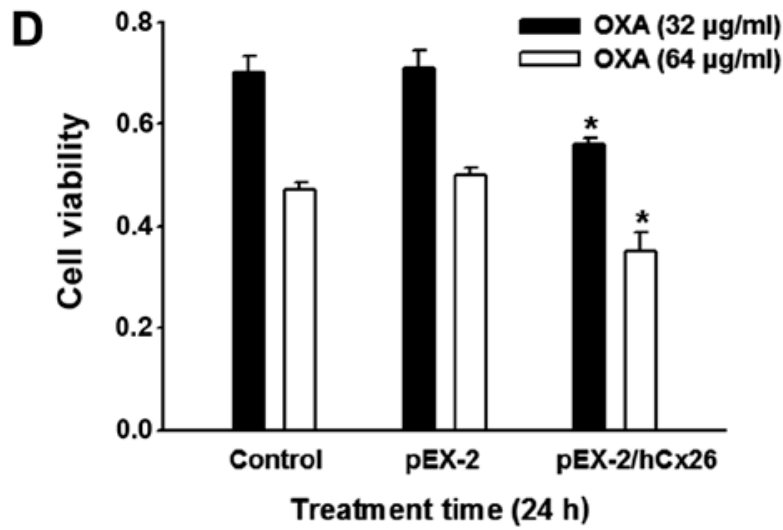

Figure 5. Effect of Cx26 overexpression on OXA cytotoxcity in SMMC-7721 cells. (A) Western blot analyses confirmed overexpression of Cx26 in SMMC-7721 cells following transfection by $\mathrm{pEX}-2 / \mathrm{hCx} 26$. (B) More membranous localization of Cx26 was observed in SMMC-7721 cells by Cx26 transfection (marked by red arrow). (C) Fluorescence images showed an enhanced dye coupling between adjacent SMMC-7721 cells by the parachute assay. (D) OXA toxicity in SMMC-7721 cells was increased by Cx26 transfection. Data represent the mean \pm SEM of four independent experiments. * $<<0.05$ vs. control.

Table III. Internalization of Cx expression in human normal liver and HCC tissues.

\begin{tabular}{|c|c|c|c|c|c|c|c|c|c|}
\hline \multirow[b]{2}{*}{ Group } & \multicolumn{3}{|c|}{$\begin{array}{c}\text { Cytoplasmic } \\
\text { Cx26 }\end{array}$} & \multicolumn{3}{|c|}{$\begin{array}{c}\text { Cytoplasmic } \\
\text { Cx32 }\end{array}$} & \multicolumn{3}{|c|}{$\begin{array}{c}\text { Cytoplasmic } \\
\text { Cx43 }\end{array}$} \\
\hline & $\mathrm{n}$ & - & + & $\mathrm{n}$ & - & + & $\mathrm{n}$ & - & + \\
\hline Normal liver & 20 & 17 & 3 & 20 & 14 & 6 & 18 & 14 & 4 \\
\hline $\mathrm{HCC}$ & 36 & 0 & 36 & 33 & 0 & 33 & 46 & 0 & 46 \\
\hline$\chi^{2}$-value & \multicolumn{3}{|c|}{43.938} & \multicolumn{3}{|c|}{31.392} & \multicolumn{3}{|c|}{41.358} \\
\hline $\mathrm{p}$-value & \multicolumn{3}{|c|}{0.000} & \multicolumn{3}{|c|}{0.000} & \multicolumn{3}{|c|}{0.000} \\
\hline
\end{tabular}

Effect of specific regulation of SMMC-7721 Cx expression on OXA cytotoxicity. To verify that the effects of cell density and the drugs on OXA cytotoxicity were due to GJ-mediated cellcell communication, RNA interference of the dominant Cxs was conducted in SMMC-7721 cells. After inhibition of Cx26, Cx32 and Cx43 expression was confirmed by western blot analysis (Fig. 4A), 'parachute' dye transfer assay demonstrated that $\mathrm{Cx} 26$ and $\mathrm{Cx} 32$ downregulation led to decreased GJs, but not Cx43 (Fig. 4B). These observations are important as they indicate the effective component of GJs in SMMC-7721 cells. Further studies showed that only the knockdown of $\mathrm{Cx} 26$, but not Cx32 or Cx43 expression depressed OXA toxicity (Fig. 4C). We further explored the effect of overexpression of $\mathrm{Cx} 26$ by transfection of $\mathrm{pEX}-2 / \mathrm{hCx} 26$. Western blot confirmed that 
Normal liver

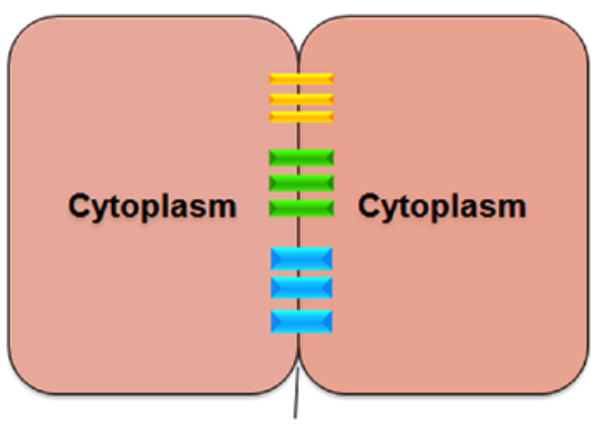

Membrane

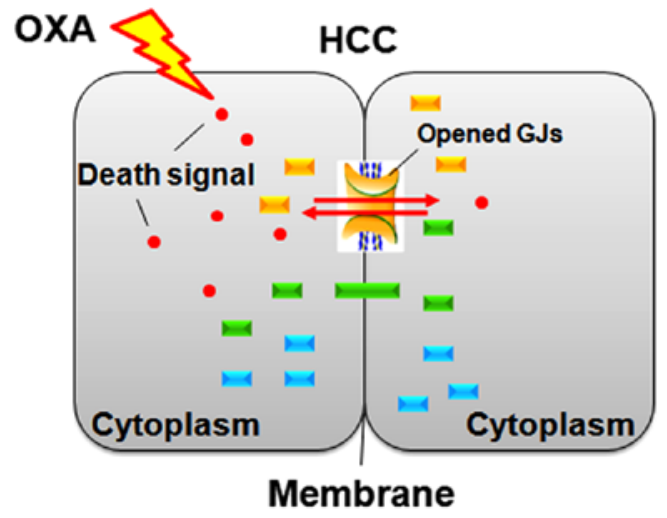

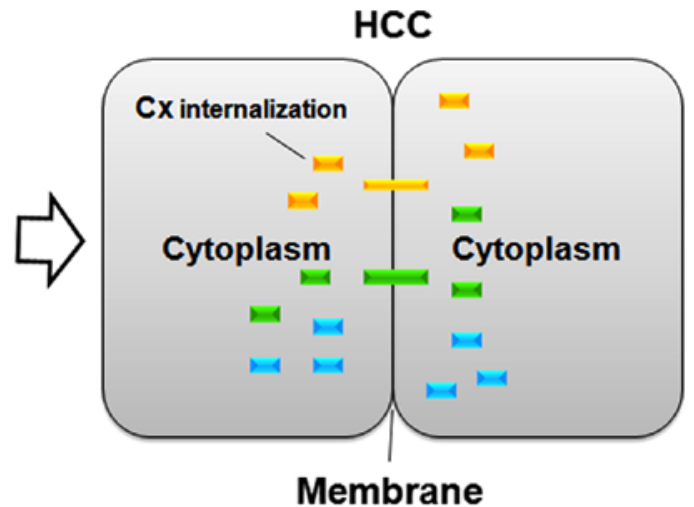

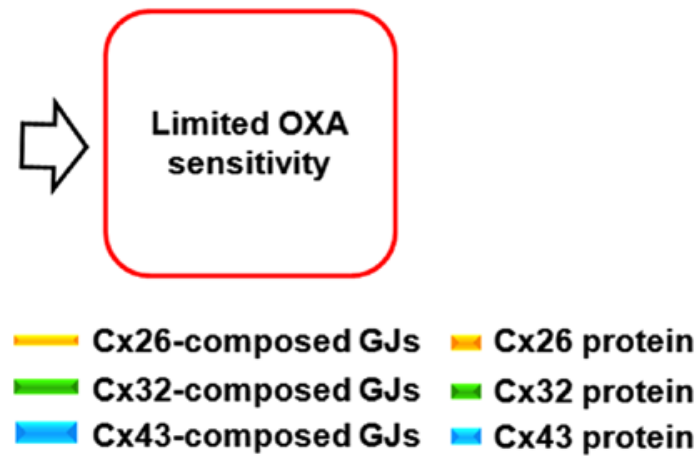

Figure 6. A proposed model for an inherent defective GJs to limit OXA-induced toxicity in HCC cells. HCC cells orchestrate impaired GJs due to the reduced expression and internalization of dominant $\mathrm{Cx}$ proteins, leading to low intrinsic OXA chemosensitivity. The effective component responsible for this effect is attributed to $\mathrm{Cx} 26$, not $\mathrm{Cx} 32$ or $\mathrm{Cx} 43$.

the expression of Cx26 was markedly enhanced relative to its untreated counterparts and pEX-2 negative controls (Fig. 5A). Accompanied by Cx26 upregulation, more Cx26 particles were located on SMMC-7721 cell membrane (Fig. 5B), and 'parachute' dye-coupling assay confirmed an increased GJ function (Fig. 5C). Expectedly, SMMC-7721 OXA cytotoxicity was finally strengthened by the upregulation of $\mathrm{Cx} 26$ expression (Fig. 5D). These results together demonstrate that the $\mathrm{Cx} 26$ protein component was specifically responsible for the role of SMMC-7721 GJs in OXA toxicity.

\section{Discussion}

Studies have demonstrated that injury or death signals induced by cytotoxic drugs such as platinum-based agents have the potential to be transferred between adjacent tumor cells via GJs, leading to the cytotoxicity amplified (10-12). Therefore, the final anti-tumor effect of chemotherapeutic drugs depends largely on the tumor GJ levels. However, Cx and its composed GJs are frequently reduced or absent in cancer cells compared with the original normal tissue $(33,34)$. GJ abnormalities compromise the regulatory framework of the organism to certain initial transformed cells, resulting in malignant tumors followed by uncontrolled excessive proliferation. Based on these findings, it is plausible that GJ decline limits the transmission of toxic signal induced by chemotherapeutic drugs between adjacent cells, resulting in restricted drug sensitivity or even drug resistance in its targeted cells (Fig. 6). It may be a mechanism underlying the poor chemotherapeutic response in tumors such as HCC. To verify the hypothesis, we first investigated the differences in $\mathrm{Cx}$ expression between $\mathrm{HCC}$ and normal liver tissues in histological specimens using a relatively large number of samples. Human normal liver cell line and $\mathrm{HCC}$ cell line were then used in vitro to confirm the Cx expression profile and its GJ status, and the role of GJs in mediating OXA cytotoxicity was also explored.

The present study showed that expressions of Cx26, Cx32 and $\mathrm{Cx} 43$ decreased significantly in human HCC tissues compared with normal liver tissues, which was in accordance with the results of liver cancer animal model (20). Further, we noted marked localization changes for the three Cxs: in normal liver tissues they were located mainly on the intercellular membranes of hepatocytes. In HCC tissues, they were located in the cytoplasm mainly, due to 'internalization', which was discovered in a prior study focused on the role of Cx32 in HCC development (22). Considering the dominant liver $\mathrm{Cx}$ proteins exhibit a similar pattern, $\mathrm{Cx}$ internalization may be a significant marker of hepatocarcinogenesis. GJs channels are formed by the end-to-end docking of two hemichannels in adjacent cells, and functional GJs occur only when Cxs are located on the membrane. Thus, an internalization of $\mathrm{Cx}$ proteins may lead to depressed or deficient GJs. Note is that Cx membranous localization is still retained in a few HCC cases, suggesting a theoretical possibility of GJ formation. We then indeed confirmed in subsequent in vitro experiments that functional GJs were reduced in human HCC cell line SMMC-7721 compared with the normal liver cell line LO2, due to reduced $\mathrm{Cx}$ expression and aberrant localization of the dominant $\mathrm{Cx}$ 
proteins. From the localization of $\mathrm{Cx}$ by immunofluorescence assay, we inferred $\mathrm{Cx} 43$ was not the main effective component of SMMC-7721 GJs.

Human liver cancer tissues or cells retain partial GJs enabling observation of the influence of GJ regulation on OXA cytotoxicity. GJ is the direct channel communicating with the adjacent cytoplasm, suggesting that the growth and confluence were proportional to GJ formation in cells with $\mathrm{Cx}$ expression. We found that OXA cytotoxicity in high density cultures (with GJ formation) was substantially greater than that of low density cultures (without GJ formation), showing that cell density affected OXA cytotoxicity. In addition to promoting GJ formation, the intimate contact between cells occurred via other mechanisms such as increased adherent proteins or vascular endothelial growth factor (VEGF) affecting cell growth and drug action $(35,36)$. Subsequent experiments of pharmacologic modulation of GJs by chemical agents elucidated an additional positive relationship between GJs and OXA toxicity. To more directly assess the role of GJs in cell density-dependent OXA sensitivity, and also determine its effective component, we explored the effects of specific alteration of SMMC-7721 Cx expression using knockdown of Cxs expression with RNA interference and Cx overexpression by gene transfection. Data showed that knockdown of Cx26 expression depressed OXA toxicity. Conversely, upregulation of Cx26 expression enhanced OXA toxicity. The differences of OXA cytotoxicity mediated by $\mathrm{Cx}$ and cell density were similar, suggesting that OXA cytotoxicity was mediated by Cx26-composed GJs.

The role of GJs composed of different $\mathrm{Cx}$ subtypes in regulating OXA cytotoxicity was distinct. We found that specifically the inhibition of $\mathrm{Cx} 26$, not $\mathrm{Cx} 32$ or Cx43 expression, decreased OXA cytotoxicity. Additionally, upregulation of Cx26 expression enhanced GJ formation and ultimately OXA toxicity. It is not surprising that $\mathrm{Cx} 43$ expression knockdown did not affect the anti-tumor effect of OXA, as it may not be the main Cx isoform for GJs in SMMC-7721 cells. Its deficiency in modulating OXA toxicity, together with the results from initial cytologic study, strongly suggested a non-GJ-dependent Cx43 function in SMMC-7721 cells. Cx26 and $\mathrm{Cx} 32$ both have the potential to form liver GJs based on histologic and cytologic results, however, Cx32 did not exert any effect on OXA toxicity. The reason may be that the GJ channels, composed of different $\mathrm{Cxs}$, mediate varying signal transduction $(23,24)$. For example, Cx expression is cell- and tissue-specific, with multiple Cxs associated with unique functions (7). The transfection of Cx26 gene into HepG2 hepatoma cells localized to the membrane, inducing the recovery of GJ function, and reduced the malignant phenotype. However, Cx32 did not exhibit this function (37). The result was similar to our present study, confirming the idea that different $\mathrm{Cx}$ proteins perform different physiological and pathological functions (38). Similarly, the Cx component determines the selectivity of GJ channels for signaling ligands, and may thus result in the differential permeability to death or injury signal molecules induced by OXA.

In the present study, the toxic signals induced by OXA were propagated by $\mathrm{Cx} 26$ channels more easily or were specifically permeable to this channel, which may explain the discrepancy of OXA toxicity following siRNA knockdown of distinct $\mathrm{Cx}$ in targeted SMMC-7721 cells (Fig. 6). We believe that these signals include the toxic OXA itself and its metabolites, or the molecules mediating the cellular death pathway. OXA and its cytoplasmic species have a molecular mass of about $400 \mathrm{Da}$, lower than the upper limit of GJ permeability. Alternatively, following OXA treatment of SMMC-7721 cells for $24 \mathrm{~h}$, the induction and transfer of relevant proteins such as cyclins, apoptosis-related proteins and DNA injury-linked proteins cannot be ruled out $(39,40)$. However, further studies are needed to explore the explicit signal molecules mediating the process.

In conclusion, histologic and cytologic data consistently demonstrate reduced expression and aberrant localization of the three dominant $\mathrm{Cx}$ proteins including $\mathrm{Cx} 26, \mathrm{Cx} 32$ and Cx43, abrogating the function of GJs in HCC tissues and cells significantly. Downregulated GJs comprising Cx26 specifically, but not Cx32 or Cx43 limited OXA cytotoxicity. Targeting Cx26 and even transiently increasing its expression, or reversing its internalization may represent an effective therapeutic strategy in liver cancer treatment.

\section{Acknowledgements}

This study was supported by the National Natural Science Foundation of China (no. 81402514), the grant from the Natural Science Foundation of Anhui Province (no. 1408085QH166), the Natural Science Research key Project of Education Office of Anhui Province (no. KJ2014A152), and internal grant from Bengbu Medical College (no. Bykf13A12).

\section{References}

1. Wu Q, Qin SK, Teng FM, Chen CJ and Wang R: Lobaplatin arrests cell cycle progression in human hepatocellular carcinoma cells. J Hematol Oncol 3: 43, 2010.

2. Zaanan A, Williet N, Hebbar M, Dabakuyo TS, Fartoux L, Mansourbakht T, Dubreuil O, Rosmorduc O, Cattan S, Bonnetain F, et al: Gemcitabine plus oxaliplatin in advanced hepatocellular carcinoma: A large multicenter AGEO study. J Hepatol 58: 81-88, 2013

3. Qin S, Bai Y, Lim HY, Thongprasert S, Chao Y, Fan J, Yang TS, Bhudhisawasdi V, Kang WK, Zhou Y, et al: Randomized, multicenter, open-label study of oxaliplatin plus fluorouracil/ leucovorin versus doxorubicin as palliative chemotherapy in patients with advanced hepatocellular carcinoma from Asia. J Clin Oncol 31: 3501-3508, 2013.

4. Petrelli F, Coinu A, Borgonovo K, Cabiddu M, Ghilardi M, Lonati V and Barni S: Oxaliplatin-based chemotherapy: A new option in advanced hepatocellular carcinoma. a systematic review and pooled analysis. Clin Oncol (R Coll Radiol) 26: 488-496, 2014.

5. Abdel-Rahman O: Revisiting oxaliplatin-based regimens for advanced hepatocellular carcinoma. Curr Oncol Rep 16: 394, 2014.

6. Miao J, Chen GG, Chun SY, Chak EC and Lai PB: Bid sensitizes apoptosis induced by chemotherapeutic drugs in hepatocellular carcinoma. Int J Oncol 25: 651-659, 2004.

7. Vinken M, Vanhaecke T, Papeleu P, Snykers S, Henkens T and Rogiers V: Connexins and their channels in cell growth and cell death. Cell Signal 18: 592-600, 2006.

8. Brockmeyer P, Jung K, Perske C, Schliephake H and Hemmerlein B: Membrane connexin 43 acts as an independent prognostic marker in oral squamous cell carcinoma. Int J Oncol 45: 273-281, 2014.

9. Krutovskikh VA, Piccoli C and Yamasaki H: Gap junction intercellular communication propagates cell death in cancerous cells. Oncogene 21: 1989-1999, 2002.

10. Jensen R and Glazer PM: Cell-interdependent cisplatin killing by $\mathrm{Ku} / \mathrm{DNA}$-dependent protein kinase signaling transduced through gap junctions. Proc Natl Acad Sci USA 101: 6134-6139, 2004. 
11. Tanaka M and Grossman HB: Connexin 26 gene therapy of human bladder cancer: Induction of growth suppression, apoptosis, and synergy with Cisplatin. Hum Gene Ther 12: 2225-2236, 2001.

12. Shishido SN and Nguyen TA: Gap junction enhancer increases efficacy of cisplatin to attenuate mammary tumor growth. PLoS One 7: e44963, 2012.

13. Yoon SY, Robinson CR, Zhang H and Dougherty PM: Spinal astrocyte gap junctions contribute to oxaliplatin-induced mechanical hypersensitivity. J Pain 14: 205-214, 2013.

14. Bai C, Yang M, Fan Z, Li S, Gao T and Fang Z: Associations of chemo- and radio-resistant phenotypes with the gap junction, adhesion and extracellular matrix in a three-dimensional culture model of soft sarcoma. J Exp Clin Cancer Res 34: 58, 2015.

15. Mesnil M: Connexins and cancer. Biol Cell 94: 493-500, 2002.

16. Cronier L, Crespin S, Strale PO, Defamie N and Mesnil M: Gap junctions and cancer: New functions for an old story. Antioxid Redox Signal 11: 323-338, 2009.

17. Vinken M, De Kock J, Oliveira AG, Menezes GB, Cogliati B, Dagli ML, Vanhaecke T and Rogiers V: Modifications in connexin expression in liver development and cancer. Cell Commun Adhes 19: 55-62, 2012.

18. Zhang JT and Nicholson BJ: The topological structure of connexin 26 and its distribution compared to connexin 32 in hepatic gap junctions. J Membr Biol 139: 15-29, 1994.

19. Maes M, Decrock E, Cogliati B, Oliveira AG, Marques PE, Dagli ML, Menezes GB, Mennecier G, Leybaert L, Vanhaecke T, et al: Connexin and pannexin (hemi)channels in the liver. Front Physiol 4: 405, 2014

20. Plante I, Charbonneau M and Cyr DG: Decreased gap junctional intercellular communication in hexachlorobenzene-induced gender-specific hepatic tumor formation in the rat. Carcinogenesis 23: 1243-1249, 2002.

21. Ma XD, Sui YF and Wang WL: Expression of gap junction genes connexin 32, connexin 43 and their proteins in hepatocellular carcinoma and normal liver tissues. World J Gastroenterol 6 : 66-69, 2000.

22. Nakashima Y, Ono T, Yamanoi A, El-Assal ON, Kohno H and Nagasue N: Expression of gap junction protein connexin32 in chronic hepatitis, liver cirrhosis, and hepatocellular carcinoma. J Gastroenterol 39: 763-768, 2004.

23. Bevans CG, Kordel M, Rhee SK and Harris AL: Isoform composition of connexin channels determines selectivity among second messengers and uncharged molecules. J Biol Chem 273: 28082816, 1998.

24. Ayad WA, Locke D, Koreen IV and Harris AL: Heteromeric, but not homomeric, connexin channels are selectively permeable to inositol phosphates. J Biol Chem 281: 16727-16739, 2006.

25. Zheng R, Wang J, Wu Q, Wang Z, Ou Y, Ma L, Wang M, Wang J and Yang Y: Expression of ALDH1 and TGF $\beta 2$ in benign and malignant breast tumors and their prognostic implications. Int $\mathrm{J}$ Clin Exp Pathol 7: 4173-4183, 2014.

26. He XD, Wang Y, Wu Q, Wang HX, Chen ZD, Zheng RS, Wang ZS, Wang JB and Yang Y: Xuebijing protects rats from sepsis challenged with acinetobacter baumannii by promoting Annexin A1 expression and inhibiting proinflammatory cytokines secretion. Evid Based Complement Alternat Med 2013: 804940, 2013.
27. Yang Y, Qin SK, Wu Q, Wang ZS, Zheng RS, Tong XH, Liu H, Tao L and He XD: Connexin-dependent gap junction enhancement is involved in the synergistic effect of sorafenib and all-trans retinoic acid on HCC growth inhibition. Oncol Rep 31: 540-550, 2014

28. Yang Y, Cao MH, Wang Q, Yuan DD, Li L and Tao L: The effects of 2-aminoethoxydiphenyl borate and diphenylboronic anhydride on gap junctions composed of Connexin43 in TM(4) sertoli cells. Biol Pharm Bull 34: 1390-1397, 2011.

29. Eugenín EA, Eckardt D, Theis M, Willecke K, Bennett MV and Saez JC: Microglia at brain stab wounds express connexin 43 and in vitro form functional gap junctions after treatment with interferon-gamma and tumor necrosis factor-alpha. Proc Natl Acad Sci USA 98: 4190-4195, 2001.

30. Garg S, Md Syed M and Kielian T: Staphylococcus aureusderived peptidoglycan induces $\mathrm{Cx} 43$ expression and functional gap junction intercellular communication in microglia. J Neurochem 95: 475-483, 2005.

31. Sáez CG, Velásquez L, Montoya M, Eugenín E and Alvarez MG: Increased gap junctional intercellular communication is directly related to the anti-tumor effect of all-trans-retinoic acid plus tamoxifen in a human mammary cancer cell line. J Cell Biochem 89: 450-461, 2003.

32. Wang J, Dai Y, Huang Y, Chen X, Wang H, Hong Y, Xia J and Cheng B: All-trans retinoic acid restores gap junctional intercellular communication between oral cancer cells with upregulation of $\mathrm{Cx} 32$ and $\mathrm{Cx} 43$ expressions in vitro. Med Oral Patol Oral Cir Bucal 18: e569-e577, 2013.

33. Mesnil M, Crespin S, Avanzo JL and Zaidan-Dagli ML: Defective gap junctional intercellular communication in the carcinogenic process. Biochim Biophys Acta 1719: 125-145, 2005.

34. Leithe E, Sirnes S, Omori Y and Rivedal E: Downregulation of gap junctions in cancer cells. Crit Rev Oncog 12: 225-256, 2006.

35. Dejana E, Orsenigo F, Molendini C, Baluk P and McDonald DM: Organization and signaling of endothelial cell-to-cell junctions in various regions of the blood and lymphatic vascular trees. Cell Tissue Res 335: 17-25, 2009.

36. Lampugnani MG and Dejana E: The control of endothelial cell functions by adherens junctions. Novartis Found Symp 283: 4-13; discussion 13-17, 238-241, 2007.

37. Yano T, Hernandez-Blazquez FJ, Omori Y and Yamasaki $\mathrm{H}$ : Reduction of malignant phenotype of HEPG2 cell is associated with the expression of connexin 26 but not connexin 32 Carcinogenesis 22: 1593-1600, 2001

38. Yamasaki $\mathrm{H}$ and Naus CC: Role of connexin genes in growth control. Carcinogenesis 17: 1199-1213, 1996.

39. Wang Z, Zhou J, Fan J, Qiu SJ, Yu Y, Huang XW, Sun J, Tan CJ and Dai Z: Oxaliplatin induces apoptosis in hepatocellular carcinoma cells and inhibits tumor growth. Expert Opin Investig Drugs 18: 1595-1604, 2009.

40. Gao J, Wang R, Yang Q, Chen C and Wu Q: Effect of Oxaliplatin on cell cycle of hepatocellular carcinoma cell line HepG2. Zhejiang Da Xue Xue Bao Yi Xue Ban 42: 437-442, 2013 (In Chinese). 